УДК 37.014.5:[37.011.3-051:005.336.2](438:4-6СС)

UDC 37.014.5:[37.011.3-051:005.336.2](438:4-6CC)

DOI: $10.31475 /$ ped.dys.2019.27.03

ОЛЬГА БІЛЯКОВСЬКА,

кандидат педагогічних наук, доцент (Україна, Львів, Львівський національний університет ілені Івана Франка, вул. Університетська, 1)

OLHA BILYAKOVSKA,

Candidate of Pedagogical Sciences, Associate Professor (Ukraine, Lviv, Ivan Franko National University of Lviv, Universytetska str., 1)

ORCID: 0000-0003-2880-6826

\title{
Концептуалізація якості підготовки майбутніх вчителів в системі професійної освіти Республіки Польща
}

\section{Conceptualization of Quality of the Future Teacher Training in the System of Professional Education in the Republic of Poland}

У статті висвітлюеться проблела якості профбесійної підготовки майбутніх вчителів у Республіці Польща. Відмічено, що важливим поштовхол щодо модернізаціӥ пробесійної підготовки майбутніх вчителів у Республіці Польща були освітні рефорли, що відбулися на початку 90-х рр. XX ст. Втілення рефборл призвело до радикальних змін у державній освітній політиці та спрялуванню системи освіти на шлях забезпечення якості. Зауважено, шо Республіка Польща, обравши європейський вектор розвитку, у питанні підготовки фбахівців, зокрела й майбутніх вчителів, орієнтується на кращі приклади країн ЄС. На основі аналізу наукових джерел розглянуто якість підготовки майбутніх вчителів з огляду на основну парадигму в якій вона здійснюеться. Зокрема, профбесійна підготовка має реалізовуватися таким чином, аби майбутні вчителі одержали можливість розкрити суть та сенс свого покликання. 3 огляду на це, персоналістична парадигма підготовки майбутніх вчителів $\varepsilon$ найбільш відповідною щодо забезпечення якості. Відзначено, що досягнення високих стандартів у ході профбесійної підготовки вчителів щодо виконання майбутньої профбесійної ролі можливе лише завдяки синергії акаделічної теорії та практики, які доповнюють одна одну під час навчання.

Ключові слова: пробесійна підготовка, майбутні вчителі, якість підготовки, освітня політика, педагогічна практика.

The article deals with the problem of quality of the future teacher training in the Republic of Poland. It is stated that the education reforms of the beginning of the 1990-s gave a strong impetus for modernization of teacher training in the Republic of Poland. The implementation of the reforms led to radical changes in the state education policy as well as in the direction of the system of education to quality assurance. The Republic of Poland is seen to focus on the best EU examples by choosing the European vector of development in the sphere of professional training, notably teacher training. Based on scientific resources, quality of teacher training is studied considering the main paradigm of its realization. In particular, professional training must be realized in such a way that future teachers can get an opportunity to discover essence and meaning of their vocation. Taking this fact into consideration, a personality-oriented paradigm of teacher training is the most relevant to quality assurance. It is noted that humanistic and axiological approaches in teacher training should be aimed at the development of teacher's personality, system of values, motives for innovative and creative activity, formation of selfawareness and self-development skills, but not only at professionally significant knowledge and skills. The main drawback in ensuring quality of teacher training is the focus on theoretical knowledge rather than methodological and practical knowledge. The key task in quality assurance of teacher training involves development of a reliable educational programme and defining effective ways of its realization. Reaching high standards of a future professional role in the process of teacher training is considered to be possible only due to the synergy of academic theory and practice that complement each other during training.

Key words: professional training, future teachers, quality of training, education policy, pedagogical practice. 
Вступ / Introduction. В умовах модернізації вітчизняної освітньої системи в контексті вимог європейського освітнього простору, впровадження Концепції Нової української школи, актуалізуеться проблема якісної професійної підготовки майбутніх вчителів, які зможуть знаходити відповіді на сучасні виклики, успішно розв'язувати професійні завдання. 3 огляду на це, корисним $\varepsilon$ накопичений зарубіжними країнами досвід щодо якості підготовки майбутніх вчителів, який можна використати й адаптувати у систему української вищої педагогічної освіти. Власне, в цьому контексті доцільно ознайомитися з освітнім досвідом Республіки Польща, як країни, що має схожі ментальнокультурні традиції й активно впроваджуе прогресивні европейські цінності.

Мета та завдання / Aim and Tasks. Мета статті полягае у здійсненні теоретичного аналізу проблеми професійної підготовки майбутніх вчителів у Республіці Польща у контексті забезпечення якості. Для реалізації мети були окреслені завдання: розглянути питання якості професійної підготовки майбутніх вчителів в доробках польських науковців; виявити проблеми та окреслити головні підходи щодо забезпечення якості професійної підготовки.

Методи / Methods. Під час дослідження було використано комплекс взаємопов'язаних методів: критичний аналіз проблеми на основі осмислення наукових психолого-педагогічних праць, синтез, систематизація й узагальнення результатів наукових пошуків.

Результати / Results. Важливим поштовхом щодо модернізації професійної підготовки майбутніх вчителів у Республіці Польща були освітні реформи, які відбулися на початку 90 -х років $\mathrm{XX}$ століття, докорінно змінили державну освітню політику, спрямувавши систему освіти на шлях забезпечення якості. Зокрема, з вересня 1999 р. почався процес впровадження освітньої реформи, особливість якої полягала в тому, що відбулося поєднання витрат на освіту з економічними та соціальними наслідками, тобто поеднання витрат з якістю освіти (Golik J., 2015). Власне необхідність змін в освітній галузі, на переконання Й. Орчика (Orczyka J., 2008), виникла 3 потреби адаптувати польську систему освіту до нових соціальних, політичних та економічних умов. Структурні зміни в системі освіти мали призвести до кращого функціонування існуючих організаційних освітніх структур «шляхом більш ефективного використання витрат, введення вимірювань результатів навчання на певних етапах освіти, зміни у правилах набору та підтримання дослідницького духу пошуку (такого важливого в процесі підготовки)». Отож, польська система освіти постала перед важливим викликом - покращення якості підготовки фахівців, адаптацією до потреб нового ринку праці, економіки високопродуктивних послуг, інформаційної економіки та економіки, заснованої на знаннях (Golik J., 2015).

На думку С. Квятковського (Kwiatkowski S., 2001), реформа системи освіти, зокрема й професійної, повинна не лише інтегрувати всі освітні системи (шкільну, вищу, післядипломну), а й координувати підтвердження професійної кваліфікації майбутнього вчителя, включати навчання впродовж життя, професійне стажування та організаційне вдосконалення. Підвищення якості підготовки вимагае не лише організаційних змін, а головно - «іншої підготовки вчителів та інвестицій в інфраструктуру освітніх закладів. Лише суттева модифікація та вдосконалення підготовки вчителів при одночасній організаційно-технічній модернізації закладів освіти створюе умови, в яких структурні та програмні зміни можуть принести очікувані результати».

Зауважимо, що Республіка Польща, обравши европейський вектор розвитку, у питанні підготовки фахівців, зокрема й майбутніх вчителів, оріентуеться на кращі приклади країн ЄС (Швеція, Фінляндія, Голландія та ін.). Ф. Шльосек (Szlosek F., 2000) відзначае з цього приводу: «Серед країн, які впровадили одну з найкращих у нашому столітті (двадцятому - авт.) реформ, варто назвати Швецію. Важливим для польської системи освіти є досвід шведських педагогів i політиків. Досвід цей можна окреслити певними принципами, найважливішими 3 яких є: 1) ефективна реалізація шкільної реформи вимагає більш тривалого часу, систематичного та водночас поступневого виконання їі завдань, а також старанного виконання запланованих пілотних досліджень; 2) послідовний хід реформи передбачае централізоване управління, а також гармонійну співпрацю влади з учителями та педагогічними управлінцями; 3) остаточні висновки реформи певним чином залежать від педагогічних досліджень, які повинні їі випереджати, постійно супроводжувати та бути використовуваними під час оцінювання їі результатів; 4) кінцевою умовою реалізації освітньої реформи є фрінансові затрати, пропорційні щодо її цілей i завдань, а також добре підготовлені кадри, загалом вчителі й адміністративні працівники освітньої сферия.

Як зазначено в «Національній стратегії розвитку до 2020 року» (Strategia Rozwoju Kraju 2020, 2012) в Республіці Польща відбувається розбудова суспільства в основі якого - знання, а тому важливого значення набуває підвищення якості вищої освіти для розвитку людського капіталу. В Стратегії, окрім акценту на потребі якісного розвитку вищої школи, головним трендом виступае система підготовки сучасних вчителів, підгрунтям якої повинні слугувати такі аспекти, як: широкий профіль навчання, відкритість та інноваційність, гнучкість і гуманізація, 
проспективність і законність, гармонійна підготовка вчителя до різних функцій, ознайомлення 3 технічними джерелами суспільної комунікації, опанування іноземними мовами, а також верифікована раціональність зв'язків між професійною, загальнопедагогічною та методичнодіяльнісною підготовкою.

Безумовно, що проблема якісної підготовки майбутніх вчителів $е$ актуальним викликом для сучасної вищої школи. Розвиток інтелектуально-пізнавальних та емоційно-соціальних процесів майбутнього вчителя певним чином залежить від якості професійної підготовки. В умовах постійних змін суспільної реальності та нових наукових досягнень змінюеться роль вчителя, головна ффункція якого полягає в участі та партнерстві у процесі вихованні дітей та молоді. Теперішній вчитель повинен уміти вчитися, вирішувати освітні проблеми, бути творчою особистістю (Niezgoda M., 1998). Перед майбутнім учителем постають важливі завдання - вміло організувати освітній простір, забезпечити розвиток учня, познайомити його зі світом вимог сучасної цивілізації та сприяти готовності до нових життевих викликів. Я. Ушинська-Ярмоч (Uszyńska-Jarmoc J., 2015) звертае увагу на якісну професійну підготовку, яка дозволить майбутньому вчителеві подорожувати непрокладеними навчальними стежками, наголошуючи при цьому, що основне завдання вчителя - постійно оновлювати власну освітню мапу, яка має відповідати існуючій реальності в якій проходить процес його професійної діяльності.

Нам імпонують погляди А. Малец (Malec A., 2018), яка пропонуе розглядати якість підготовки майбутніх вчителів з огляду на основну парадигму в якій вона здійснюеться. Дослідниця зазначає, що домінуюча в підготовці вчителів біхевіористична парадигма, полягає у наданні готових знань, відомостей та зразків професійної поведінки й означае, що вчитель не бере участі в окресленні цілей навчання, не ставить під сумнів їх легітимність, реалізуе пропоновану програму, не може уявити викладання без підручника, власне не $е$ рефлексивним. Водночас, якщо підготовка проходитиме відповідно до гуманістичної парадигми, то для такого вчителя в центрі уваги й інтересів буде розвиток учня. У процесі підготовки майбутній вчитель демонструватиме самопізнання, емпатію та навички спілкування, а також реалізуватиме міжособистісні відносини. Адже, на переконання Ф. Знанієцького (Znaniecki F., 2001), гуманістичне навчання опирається на універсальні цінності: добро, краса, правда, а людина-гуманіст, яким е майбутній вчитель, це людина добра і мудра, покликання якої - слугувати цінностям та творити. Зокрема науковець зауважуе, що цінності становлять сутність людини, оскільки е «джерелом оптимальної активності особистості, яка є вільною, відповідальною, мудрою та щоденно зорієнтованою на свідомий вибір, прийняття та реалізацію цінностей».

Водночас у дискусіях стосовно якісної професійної підготовки майбутніх вчителів акцентуеться на її «науковому, функціональному та професійному характері», але «визначальним е глибокий $\mathrm{i}$ правдивий гуманістичний вимір». Функціональність, як зазначае З. Маркоцький (Markocki Z., 2009) передбачае, окрім учіння, опанування цінностей і вмінь, та ще й використання їх на практиці.

Конструктивістська парадигма у підготовці майбутніх вчителів формуватиме педагогів, які у подальшій професійній діяльності підтримуватимуть природну взаємодію дитини з суспільством чи середовищем, що розвиваються (Malec А., 2018). Визначаючи конструктивістські підходи стосовно підготовки майбутніх вчителів як основу забезпечення ії якості, варто зазначити, що «в цьому процесі важливу роль відіграє інтеграція знань та досвіду - як власних, так і інших учасників освітніх взаємодій» (Jezierska-Wiejak E., 2018). Здатність майбутнього вчителя до роздумів про власні ресурси, усвідомлення недоліків та можливостей відіграють важливу роль у професійному становленні. Змальовуючи образ майбутнього вчителя, як вчителя конструктивіста, Й. Шимчак (Szymczak J., 2010) стверджуе, що це вчитель, «для якого рефрлексія над собою та професійною реальністю - це шанс стати відкритою людиною, позбавленою шаблонів та бути залученою, насамперед, у процес навчання». Саме тому, у процесі професійної підготовки варто задавати питання щодо очікувань майбутнього вчителя. Окрім того, важливо здійснювати різнобічний аналіз подій, заходів, учасником яких був майбутній вчитель, реалізовуючи свою професійну функщію.

Крім того, А. Малец (Malec А., 2018) розглядає парадигму критичної емансипації, в основі якої «лежить наука відстоювати сласну позицію». Однак, як зауважуе А. Малец у більшості польських університетів парадигму критичної емансипації важко реалізувати через низький інтелектуальний потенціал студентів та слабкий інтерес до навчання. Власне парадигма критичної емансипації вимагае великих затрат часу на вивчення новітньої, сучасної літератури 3 гуманітарних та суспільних наук. Таке бачення процесу професійної підготовки, на жаль, «залишаеться утопією у польській освітній системі, оскільки воно вимагае від студента (майбутнього вчителя) та викладача сміливості у навчанні, інтелектуальних та реконструкційних компетенцій». 
Зауважимо, що насущними викликами сьогодення е перетворення освітніх систем відповідно до вимог та реальних потреб XXI століття. Саме тому в основі сучасних трансформаційних процесів повинні бути кардинально різні погляди на людський інтелект та творчість. Отож, як стверджуе M. Шиманська (Szymańska M., 2019) актуалізується необхідність зосередитися на якості підготовки майбутніх вчителів, аби в процесі такої підготовки вони одержали можливість розкрити суть та сенс свого покликання. 3 огляду на це, як зауважуе дослідниця, персоналістична парадигма підготовки вчителів видаеться найбільш відповідною щодо забезпечення нової якості професійної підготовки. Адже вона дає можливість визначити цінність внутрішнього життя людини, яке в певному сенсі $е$ «командним центром» освітніх процесів, забезпечить готовність до нових викликів сьогодення. Окрім того, в підготовці майбутніх вчителів мае бути присутній такий важливий чинник, як духовність, виражена шанобливим ставленням до народних традицій та цінностей (Marek Z., 2017).

У час стрімкого розвитку технологій, мереж та всезагального дистанціювання, важливо аби професійна підготовка майбутніх учителів грунтувалася на гуманістичних і аксіологічних засадах, одночасно базуючись й на ключових компетенціях, які спрятимуть тому, що вчитель будучи «віддаленим критиком реальності, окреслюе власний вибір, шукае власний шлях, розглядає при цьому багато різних варіантів та різноманітних сценаріїв - тобто ідентифікуе загрози, ризики, витрати, щодо усвідомлення можливості вибору у світі, сповненому суперечностей» (Zacher L., 1998). Водночас гуманістичний та аксіологічно-оріентований підхід у професійній підготовці майбутніх вчителів має «бути орієнтований на розвиток їхньої особистості, систему цінностей, мотиви інноваційної та творчої діяльності, формування навичок самоаналізу та самовдосконалення, а не лише на професійно значущі знання та вміння» (Prokopiuk W., 1997).

Процес підготовки майбутніх вчителів у контексті забезпечення якості, на переконання Й. Лукасік (Łukasik J., 2012), має спрямовуватися за такими головними напрямками: предметні знання, знання дидактики та їі застосування, знання та навички у галузі виховання дітей та молоді, а також цінності, віднесені до професійної практики. Й. Лукасік на підставі якісного дослідження - результатів спостереження й анкетування вибірки молодих вчителів, зробила певні узагальнення, щодо забезпечення якості їхньої підготовки. Так, проаналізувавши відповіді респондентів на анкети, дослідниця зазначае, що теоретичні знання щодо змісту предмета, який будуть викладати вчителі, оцінюються добре і дуже добре (головний критерій - практичність та корисність). Власне тому у процесі підготовки майбутні вчителі, в основному, зосереджені на здобутті знань, які можуть бути використані у професійній діяльності (знання, що складають основну навчальної програми предмета, який буде викладатися). Теоретичні дидактичні знання оцінюються дуже добре. На жаль, як зауважуе дослідниця, повторне використання предметних знань, що мають формувати практичні навички, е слабким місцем у системі підготовки вчителів. Надлишок теорії та складність чи неможливість перевірити ї̈ на практиці (навіть під час вправ) означає, що вчителі не відчувають себе повністю готовими до викладання предмета у школі, i, як наслідок, стикаючись зі шкільною реальністю (практика, перші роки роботи в школі) це призводить до нервової напруги та стресу. Найбільші недоліки в методиці викладання предмету майбутні вчителі відчувають у застосуванні активних методів в навчальному процесі. Окрім того, знання та навички у галузі виховання дітей та підлітків оцінюються вчителями досить низько. Майже всі опитані вчителі констатували, що студії практично не готують їх до виховної роботи, вирішення проблем та навчальних ситуацій, які виникають у шкільній дійсності, а також до співпраці з батьками учнів. Зокрема респонденти наголошують, що знання та навички виховання дуже важливі та потрібні в сучасній школі.

Професійні (педагогічні) практики займають вагоме місце в системі підготовки майбутніх вчителів. Адже в ході педагогічної практики студенти можуть апробувати здобуті теоретичні дидактичні знання та навчально-виховні навички в реальних умовах шкільної дійсності. Недоліком практик є, як вказують респонденти, невелика кількість годин, в результаті чого не забезпечуеться належна практична підготовка. Саме тому після закінчення студій та з початком професійної діяльності молоді вчителі відчувають себе невпевнено та зазнають додаткового стресу (Łukasik, 2012, c. 121).

Як зазначає C. Влох (Włoch S., 2018), якість практичної підготовки е найбільш занедбаним елементом системи професійної підготовки вчителів у вищих школах впродовж останніх 25 років. Зокрема K. Денек (Denek K., 2005) окреслюе практики як Ахіллесову п’яту, а підготовку вчителів, як не реалізовану повністю, тобто, час, визначений на практику е непропорційно коротким до кількості завдань, які треба виконати протягом її тривалості, аби якісно підготувати випускників університету до вчительської праці. На думку C. Влох (Włoch S., 2018) «підготовка майбутніх вчителів може бути представлена як система, проте вона містить багато прогалин і не враховуе сучасних змін та цивілізаційних перетворень, оскільки, на жаль, все ще залишилася у стереотипах 
минулого». Головна проблема у забезпеченні якісної підготовки майбутніх вчителів полягає в концентрації на передачі теоретичних знань в збиток методичним та практичним. Відсутність зв’язку між теорією та практикою, розвитку рефрлексивності та компетентності у вирішенні освітніх проблем та дискусій (діалогу) щодо навчання та виховання сучасних дітей та молоді. Основне завдання у забезпеченні якості підготовки майбутніх вчителів С. Влох вбачає у розробленні надійної освітньої програми та визначенні ефективних шляхів її виконання.

Погоджуемося 3 думкою В. Оконя (Okoń В., 1991), який вважае, що педагогічні практики надають якісний сенс підготовці вчителів, оскільки завдяки їм студенти - майбутні вчителі: поступово дізнаватимуться про педагогічну діяльність та iㅣ складові, а також про зв'язки та залежності між ними; навчитимуться аналізувати педагогічну реальність; визнати причини власних успіхів та невдач у ході практики; вживати заходів щодо усунення неадекватної та неефективної навчальної діяльності; самостійно та свідомо виконувати більш складні та комплексні навчальні завдання; поступово починати усвідомлювати, що теорія є міцною основою для педагогічної діяльності та розвитку професійної компетентності. Як слушно зауважує В. Комар (Komar W., 2000), «досягнення високих стандартів у галузі профресійної підготовки щодо виконання майбутньої професійної ролі можливе лише завдяки синергії академічної теорії та практики, які доповнюють одна одну під час навчання». На переконання науковця «добре організована та реалізована професійна практика створюе умови для генерування професійних знань студентамайбутнього вчителя».

Обговорення / Discussion. Глобалізаційні процеси, які впливають на всі сфери життедіяльності людини, зумовлюють пошуки нових шляхів на забезпечення якості освіти, зокрема якості професійної підготовки фахівців. Стратегічним завданням державної освітньої політики кожної країни е модернізація професійної підготовки майбутніх вчителів відповідно вимог до европейського освітнього простору та пропонованої культури якості. Дослідниця С. Голіновська (Golinowska S., 2000) виокремлюе низку завдань, які постають перед сучасною польською освітою: 1) адекватна система підготовки вчителів; 2) відбір до професії викладача та мотиваційна система оплати праці; 3) модернізація програм та організації професійної освіти; 4) навчальний контроль, баланс між передачею знань та програмними навичками; 5) освіта, орієнтована на потреби ринку праці; 6) реалізація концепції «навчання протягом усього життя»; 7) забезпечення рівного доступу до освіти; 8) підвищення якості вищої освіти; 9) подолання навчальної дистанщії стосовно країн Європейського Союзу. Також, як зазначає дослідниця, у процесі інтеграції потрібно враховувати европейський контекст освітньої політики, зокрема інтеграційні процеси на всіх рівнях. Тому пріоритетами освіти, зокрема вищої є: рівні можливості навчання; підвищення якості освіти; нова модель вчителя; европейський ідеал виховання.

Проблема якісної професійної підготовки майбутніх вчителів постійно домінуе у наукових дискусіях польських дослідників освітньої галузі. Проаналізувавши дослідження, проведені педевтологами (Denek K., 1998, 2005, 2011, 2012; Czerepaniak-Walczak M., 1994, 1997; Kwiatkowska H., 1996, 1997, 2005; Gołębniak B.-D., 1998; Lewowicki T., 2007, 2010, 2011, 2013; Mieszalski S., 2013, 2015; Łukasik J., 2005, 2009, 2010; Śliwerski B., 2010, 2017; Szempruch J., 2001, 2010, 2012 та ін.) можна констатувати, що питання підготовки майбутніх вчителів у Республіці Польща е актуальним викликом та важливою й нагальною проблемою педагогічної освіти. Адже, як слушно зауважив З. Квецінський (Kwieciński Z., 1998), «педагог-вчитель - це той, хто веде молоду людину до повноти свого розвитку, веде мінливими стежинами життя з постійним вибором; хто вміе розумно радити і розрадити, піклуеться про те, щоб ніхто не став пасивним матеріалом історії великих політичних держав, але щоби був незалежним суб’єктом, творцем власної долі та співтворцем процвітання своєї громади».

Висновки / Conclusions. Отже, якість професійної підготовки майбутніх вчителів $\epsilon$ пріоритетним завданням та нагальною потребою освітньої політики кожної держави, яка прагне визнання та домінування у європейському просторі вищої освіти. Світ стрімко розвивається, технології проникають у всі суспільні сфери, змінюючи сприйняття та бачення майбутнього. Сучасна школа потребуе «нового» вчителя, компетентного фахівця, який зможе виплекати молоду людину в кращих традиціях свого народу, підготувати ï до «завтрашнього» дня. Саме тому професійна підготовка майбутніх вчителів має бути різноплановою, персонально спрямованою, змістовно збалансованою, засадничо опиратися на гуманістичні та аксіологічні принципи. До перспективних напрямків дослідження з окресленої проблеми вважаемо за доцільне віднести використання новітніх методів, технологій у забезпеченні якості професійної підготовки майбутніх вчителів. 
Список використаних джерел і літератури:

Denek, K. (2005). Ku dobrej edukacji. [w] K. Denek, \& I. Kuźniak (Red.), Przygotowanie celów kształcenia w reformowanej szkole. Torun: Akapit [in Polish].

Golik, J. (2015). Formalne kwalifikacje nauczycieli $i$ wydatki na zajęcia pozalekcyjne, a wyniki uczniów $z$ egzaminów zewnętrznych $w$ latach 2002-2011 (gimnazjów finansowanych z budżetu miasta Poznania). Rozprawa doktorska. Poznań [in Polish].

Golinowska, S. (2000). Polityka społeczna: koncepcje - instytucje - koszty. Warszawa: Wyd. Poltext [in Polish].

Jezierska-Wiejak, E. (2018). Praktyki pedagogiczne przygotowaniem do odgrywania roli nauczyciela czy wprowadzeniem do zawodu? [w] E. Musiał, J. Malinowska (Red.), Praktyki pedagogiczne przestrzenia $i$ miejscem ewaluacji kompetencji przysztych nauczycieli wczesnej edukacji: koncepcje - przemiany - rozwiazania (s. 101-113). Wrocław: Instytut Pedagogiki Uniwersytetu Wrocławskiego [in Polish].

Komar, W. (2000). Wspótczesność i nauczyciel. Perspektywy edukacji bez dogmatów? Którędy do wyksztatcenia świattych oraz niezależnie myślacych ludzi-nauczycieli: blokady i szanse? Warszawa: Żak [in Polish].

Kwieciński, Z. (1998). Nowe potrzeby i kierunki zmian kształcenia pedagogów i nauczycieli. [w] K. Pacławska (Red.), Tradycja i wyzwanie. Kraków: Wyd. Uniwersytetu Jagiellońskiego [in Polish].

Kwiatkowski, S. M. (2001). Kształcenie zawodowe: dylematy teorii i praktyki. Warszawa: IBE [in Polish].

Lukasik, J. (2012). Zmiany w kształceniu nauczycieli. Możliwe szanse - nowe wyzwania. Ruch Pedagogiczny, LXXXIII, 119-126 [in Polish].

Marek, Z. (2017). Pedagogika towarzyszenia. Perspektywa tradycji ignacjańskiej. Kraków: WAM [in Polish].

Malec, A. (2018). Przygotowanie studentów do realizacji zadań nauczyciela edukacji wczesnoszkolnej - między teorią a praktyką. [w] E. Musiał, J. Malinowska (Red.), Praktyki pedagogiczne przestrzenia $i$ miejscem ewaluacji kompetencji przyszłych nauczycieli wczesnej edukacji: koncepcje - przemiany - rozwiazania (s. 154-163). Wrocław: Instytut Pedagogiki Uniwersytetu Wrocławskiego [in Polish].

Markocki, Z. (2009). Nauczyciel - wychowawca wobec nowej rzeczywistości edukacyjnej społeczeństwa. [w] Cz. Prewka (Red.), Ku Dobrej Szkole. Nauczyciele. Technologie ksztatcenia (s. 15-21). Szczecin-Radom: PIB [in Polish].

Niezgoda, M. (1998). Kształcenie dla przyszłości. [w] K. Pacławska (Red.), Tradycja i wyzwanie. EdukacjaNiepodległość - Rozwój. Kraków: Wyd. Uniwersytetu Jagiellońskiego [in Polish].

Okoń, W. (1991). Rzecz o edukacji nauczycieli. Warszawa: WsiP [in Polish].

Orczyk, J. (2008). Polityka społeczna. Uwarunkowania i cele. Poznań: Akademia Ekonomiczna [in Polish].

Prokopiuk, W. (1997). Szkic o humanistycznym wymiarze samokształcenia nauczycieli. [w] A. A. Kotusiewicz, G. Koć-Seniuch, J. Niemiec (Red.), Myśl pedeutologiczna i działanie nauczyciela (s. 164-176). Białystok: Wyd. Akademickie «Żak» [in Polish].

Strategia Rozwoju Kraju 2020. (2012). 157 [in Polish].

Szlosek, F. (2000). Potrzeby i możliwości przygotowania nauczycieli do realizacji reformy edukacji w Polsce. [w] Ksztalcenie nauczycieli a reforma systemu edukacji w Polsce (s. 11-17). Radom: ITE [in Polish].

Szymańska, M. (2019). Portfolio w kształceniu nauczycieli. Kraków: Wyd. Ignatianum [in Polish].

Szymczak, J. (2010). Ze zdarzeniami krytycznymi w tle. Namysł nad refleksja w zawodzie nauczyciela. Teraźniejszość - Człowiek - Edukacja, 4 (52), 55-74 [in Polish].

Uszyńska-Jarmoc, J. (2015). Rozwój zawodowy nauczycieli przedszkola z perspektywy teorii kolektywizmu. [w] S. Guz, M. Centner-Guz, I. Zwierzchowska (Red.), W trosce o rozwój i wczesna edukację dziecka (s. 135-146). Lublin: Wyd. Uniwersytetu Marii Curie-Skłodowskiej [in Polish].

Włoch, S. (2018). «Uczymy inaczej» - teoria i praktyka w kształceniu nauczycieli wczesnej edukacji. [w] E. Musiał, J. Malinowska (Red.), Praktyki pedagogiczne przestrzeniq i miejscem ewaluacji kompetencji przysztych nauczycieli wczesnej edukacji: koncepcje - przemiany - rozwiazania (s. 41-51). Wrocław: Instytut Pedagogiki Uniwersytetu Wrocławskiego [in Polish].

Zacher, L. W. (1998). Problemy przyszłego świata jako wyzwania edukacyjne współczesności. [w] A. SiemakTylikowska, H. Kwiatkowska, S. M. Kwiatkowski (Red.), Edukacja nauczycielska w perspektywie zmieniajacego się świata (s. 234-246). Warszawa: Wyd. Akademickie «Żak» [in Polish].

Znaniecki, F. (2001). Ludzie teraźniejsi a cywilizacja przyszłości. Warszawa: Wyd. Naukowe PWN [in Polish].

\section{References:}

Denek, K. (2005). Ku dobrej edukacji [For Good Education]. In K. Denek, \& I. Kuźniak (Red.), Przygotowanie celów ksztatcenia w reformowanej szkole. Torun: Akapit [in Polish].

Golik, J. (2015). Formalne kwalifikacje nauczycieli $i$ wydatki na zajęcia pozalekcyjne, a wyniki uczniów z egzaminów zewnętrznych $w$ latach 2002-2011 (gimnazjów finansowanych z budżetu miasta Poznania) [Formal Qualifications of Teachers and Expenses for Extracurricular Activities, and the Results of Students from External Exams in the Years 2002-2011 (Junior High Schools Financed from the Budget of the city of Poznań)]. Doctoral dissertation. Poznań [in Polish].

Golinowska, S. (2000). Polityka społeczna: koncepcje - instytucje - koszty [Social Policy: Concepts - Institutions Costs]. Warszawa: Wyd. Poltext [in Polish].

Jezierska-Wiejak, E. (2018). Praktyki pedagogiczne przygotowaniem do odgrywania roli nauczyciela czy wprowadzeniem do zawodu? [Teaching Practices - Preparation for Playing the Role of a Teacher or Introduction to a Profession?] In E. Musiał, J. Malinowska (Red.), Praktyki pedagogiczne przestrzeniq i miejscem ewaluacji kompetencji przysztych nauczycieli wczesnej edukacji: koncepcje - przemiany - rozwiazania (pp. 101-113). Wrocław: Instytut Pedagogiki Uniwersytetu Wrocławskiego [in Polish].

Komar, W. (2000). Wspótczesność i nauczyciel. Perspektywy edukacji bez dogmatów? Którędy do wyksztatcenia świattych oraz niezależnie myślących ludzi-nauczycieli: blokady i szanse? [Contemporary and Teacher. Education 
Prospects without Dogmas? Which Way to Educate Enlightened and Independent-Thinking Teachers: Blockades and Opportunities?]. Warszawa: Żak [in Polish].

Kwieciński, Z. (1998). Nowe potrzeby i kierunki zmian kształcenia pedagogów i nauczycieli [New Needs and Directions of Changes in Educating Educators and Teachers]. In K. Pacławska (Red.), Tradycja i wyzwanie. Kraków: Wyd. Uniwersytetu Jagiellońskiego [in Polish].

Kwiatkowski, S. M. (2001). Ksztatcenie zawodowe: dylematy teorii i praktyki /Vocational Training: Dilemmas of Theory and Practice]. Warszawa: IBE [in Polish].

Lukasik, J. (2012). Zmiany w kształceniu nauczycieli. Możliwe szanse - nowe wyzwania [Changes in Teacher Education. Possible Opportunities - New Challenges]. Ruch Pedagogiczny - Pedagogical Movement, LXXXIII, 119126 [in Polish].

Marek, Z. (2017). Pedagogika towarzyszenia. Perspektywa tradycji ignacjańskiej [Accompanying Pedagogy. Perspective of the Ignatian Tradition]. Kraków: WAM [in Polish].

Malec, A. (2018). Przygotowanie studentów do realizacji zadań nauczyciela edukacji wczesnoszkolnej - między teoria a praktyka [Preparing Students to Carry out the Tasks of an Early School Education Teacher - Between Theory and Practice]. In E. Musiał, J. Malinowska (Red.), Praktyki pedagogiczne przestrzenia $i$ miejscem ewaluacji kompetencji przysztych nauczycieli wczesnej edukacji: koncepcje - przemiany - rozwiazania (pp. 154-163). Wrocław: Instytut Pedagogiki Uniwersytetu Wrocławskiego [in Polish].

Markocki, Z. (2009). Nauczyciel - wychowawca wobec nowej rzeczywistości edukacyjnej społeczeństwa [Teacher - Educator in the Face of the New Educational Reality of Society]. In Cz. Prewka (Red.), Ku Dobrej Szkole. Nauczyciele. Technologie ksztatcenia (s. 15-21). Szczecin-Radom: PIB [in Polish].

Niezgoda, M. (1998). Kształcenie dla przyszłości [Education for the Future]. In K. Pacławska (Red.), Tradycja $i$ wyzwanie. Edukacja - Niepodległość - Rozwój. Kraków: Wyd. Uniwersytetu Jagiellońskiego [in Polish].

Okon, W. (1991). Rzecz o edukacji nauczycieli [The Thing about Teacher Education]. Warszawa: WsiP [in Polish].

Orczyk, J. (2008). Polityka społeczna. Uwarunkowania i cele [Social Policy. Conditions and Goals]. Poznań: Akademia Ekonomiczna [in Polish].

Prokopiuk, W. (1997). Szkic o humanistycznym wymiarze samokształcenia nauczycieli [A Sketch on the Humanistic Dimension of Teacher Self-Education]. In A. A. Kotusiewicz, G. Koć-Seniuch, J. Niemiec (Red.), Myśl pedeutologiczna i działanie nauczyciela (s. 164-176). Białystok: Wyd. Akademickie «Żak» [in Polish].

Strategia Rozwoju Kraju 2020 [National Development Strategy 2020]. (2012). 157 [in Polish].

Szlosek, F. (2000). Potrzeby i możliwości przygotowania nauczycieli do realizacji reformy edukacji w Polsce [Needs and Opportunities to Prepare Teachers to Implement Education Reform in Poland]. In Ksztalcenie nauczycieli a reforma systemu edukacji w Polsce (pp. 11-17). Radom: ITE [in Polish].

Szymańska, M. (2019). Portfolio $w$ ksztatceniu nauczycieli [Portfolio in Teacher Education]. Kraków: Wyd. Ignatianum [in Polish].

Szymczak, J. (2010). Ze zdarzeniami krytycznymi w tle. Namysł nad refleksja w zawodzie nauczyciela [With Critical Events in the Background. Reflection on Reflection in the Teaching Profession]. Teraźniejszość - Człowiek Edukacja - Present - Man - Education, 4 (52), 55-74 [in Polish].

Uszyńska-Jarmoc, J. (2015). Rozwój zawodowy nauczycieli przedszkola z perspektywy teorii kolektywizmu [Professional Development of Kindergarten Teachers from the Perspective of Collectivism Theory

]. In S. Guz, M. Centner-Guz, I. Zwierzchowska (Red.), W trosce o rozwój i wczesnq edukację dziecka (pp. 135146). Lublin: Wyd. Uniwersytetu Marii Curie-Skłodowskiej [in Polish].

Zacher, L. W. (1998). Problemy przyszłego świata jako wyzwania edukacyjne współczesności [Future World Problems as Contemporary Educational Challenges]. In A. Siemak-Tylikowska, H. Kwiatkowska, S. M. Kwiatkowski (Red.), Edukacja nauczycielska w perspektywie zmieniajacego sie świata (pp. 234-246). Warszawa: Wyd. Akademickie «Żak» [in Polish].

Znaniecki, F. (2001). Ludzie teraźniejsi a cywilizacja przyszłości [Present People and the Civilization of the Future]. Warszawa: Wyd. Naukowe PWN [in Polish].

Дата надходження статті: «27» вересня 2019 р.

Стаття прийнята до друку: «17» жовтня 2019 р.

Біляковська Ольга - доцент кафедри загальної і соціальної педагогіки Львівського національного університету імені Івана Франка, кандидат педагогічних наук, доцент

Bilyakovska Olha - Assistant Professor of the Department of General and Social Pedagogy of Ivan Franko National University of Lviv, Candidate of Pedagogical Sciences, Associate Professor

\section{Цитуйте ию статтю як:}

Біляковська, О. (2019). Концептуалізація якості підготовки майбутніх вчителів в системі професійної освіти Республіки Польща. Педагогічний дискурс, 27, 28-34. doi: 10.31475/ped.dys.2019.27.03.
Cite this article as:

Bilyakovska, O. (2019). Conceptualization of Quality of the Future Teacher Training in the System of Professional Education in the Republic of Poland. Pedagogical Discourse, 27, 28-34. doi: $10.31475 /$ ped.dys.2019.27.03. 